\title{
PASTURE SPECIES AND CULTIVARS FOR REGIONS
}

\author{
L. CORKILL \\ Plant Breeders N ew Zealand Ltd, Christchurch \\ W. M. Willitams and J. A. Lancashire \\ Grasslands Division, DSIR, Palmerston North
}

\begin{abstract}
The origin of the pasture species grown in New Zealand and the development of ecotypes are briefly described. The effects of environmental factors such as rainfall, temperature, soil type, soil fertility, grazing pressure, and pests and diseases on plant breeding objectives and choice of species in different regions of the country are discussed. The value of incorporating plant material from Mediterranean sources into New Zealand-bred cultivars of ryegrass, white clover and Lotus is illustrated, but the importance of local plant collections in the development of cultivars such as Nui and Ellett ryegrass and a hill country white clover is also emphasized. The possibility of breeding cultivars specifically for overseas markets is discussed.
\end{abstract}

\section{INTRODUCTION}

None of the species used for sown pastures in New Zealand are native to the country. Most were indigenous to Eurasia and North Africa and prior to their arrival in this country, accidentally or intentionally, were common in the European countries from where the early settlers migrated to New Zealand. On his first voyage in 1769 and in subsequent visits, Captain Cook brought both seeds and animals, but to the early missionaries must be attributed the first organized introduction of seeds of species which were commonly used in their native lands. Marsden, in 1814, and later other missionaries, brought sheep, cattle and seeds. Six years later the first plough was operating at Kerikeri and it was there on 20 July 1821 that the first grassland was sown in New Zealand by the Rev. John Butler. By 1830 an agricultural mission school was established at Waimate North (Allan, 1937; Saxby, 1956). Since these early introductions there has been a constant flow of seeds brought into New Zealand, much of it of pasture species introduced, sown, and often increased. 
Allan (1937) considered that by far the most important factor in the entry and spread of alien species in New Zealand was purposeful introduction and sowing, both on cultivated and noncultivated land, and he estimated that at least $56 \%$ of the alien species entered and were assisted in spreading in this way. Distribution was often rapid and widespread. Guthrie-Smith (1930) cited the arrival of ryegrass in Hawke's Bay as an example of how widely seeds soon spread from the mission stations. As early as 1834 or 1835 a bag of ryegrass seed was carried overland and by canoe from Paihia to Tangoio by a Maori girl who had been educated in the Bay of Islands. The first ryegrass seed to arrive in Poverty Bay was also brought from the Bay of Islands to the mission station on the Waipaoa River where it rapidly became well established.

Since the early introductions, seed has been brought into the country continually from different sources and regions. The plant populations established here have therefore been extremely variable. It was from such wide genetic bases that the various species came to dominate in certain regions and from which New Zealand ecotypes evolved in response to the selection pressure of environmental factors.

\section{ENVIRONMENTAL FACTORS}

The major factors causing selection pressure on pasture plants and also affecting the choice of species, cultivars and mixtures for regions are considered below.

\section{SOIL TYPE}

Nutrient limitations apply on practically all usable soils in New Zealand (Gibbs, 1963) and pastoral improvement has been largely dependent on the spreading of millions of tonnes of fertilizers on to our soils (Saunders, 1980). Although recent surveys in Southland and Matamata suggest that the nutrient status of soils in some parts of the country may have reached the stage where rates of fertilizer application can be reduced (Saunders, 1980). there is little doubt that many areas, particularly on hill country, are very low in nutrients (Mauger, 1977). The correction of such deficiencies will always be a prime objective in grassland farming but with recent cost increases, particularly in the more inaccessible areas, and the possibility of reduced world supplies of some of the major elements such as phosphorus, there is little doubt that for the foreseeable future many New Zealand pastures will be growing on soils which are sub-optimal in nutrient status. Thus 
the choice, breeding and selection of species and cultivars for more efficient use of plant nutrients must be a major priority in the next few years.

A number of grass species such as browntop (Agrostis fenuis Sibth), sweet vernal (A nthoxanthum odoratum L.) , crested dogstail (Cynosurus cristatus L.) and Yorkshire fog (Holcus lanafus L.) and legumes like suckling clover (Trifolium dubium Sibth), subterranean clover ( $T$. subterraneum L.) and Lotus are more tolerant of low fertility than species such as ryegrass, white clover (T. repens L.) and lucerne (M edicago sativa L.) . In particular, the recently released cultivar of Lotus pedunculatus Cav., 'Grasslands Maku', is proving very useful as an alternative to white clover at a number of low-fertility sites (Nordmeyer and Davis, 1977; Lowther, 1977). The cultivar has some serious agronomic deficiencies such as very slow regrowth after defoliation, when compared with white clover (Brock and Charlton, 1978; Sheath 1981), and this emphasizes the importance of developing white clover cultivars which will grow successfully under lower fertility conditions (Caradus and Dunlop, 1978).

In addition, it is important that programmes should be encouraged for the improvement and utilization of other legumes and grasses tolerant of low fertility such as birdsfoot trefoil (Lotus corniculatus L.) , subterranean clover, browntop, crested dogstail, and Yorkshire fog, of which a new cultivar 'Massey Basyn' was recently released (Jacques, 1974) .

Soil moisture deficiencies will be considered in the next section but it should not be forgotten that there are large areas of soils in New Zealand where excess water limits pasture growth and utilization, particularly in winter. In cases where drainage is not possible or not completely satisfactory, species such as Yorkshire fog, lotus and tall fescue (Festuca arundinacea Schreb.) offer an alternative to standard pasture mixtures on peat (Goold and Hupkens van der Elst, 1980) and pakihi soils (Morton, 1981).

It has been estimated that the production of over two million hectares of potentially productive grassland is limited by problems of instability and erosion (Gibbs, 1963). New approaches or, at least, the re-activation of some old ideas to solve this problem include the mixed planting of trees and pasture (Campbell, 1947; Farnsworth et al., 1975; Blakemore, 1978) and the use of grass species such as phalaris (Phalaris aquatica L.) (King, 1969) which have excellent soil-binding properties. 


\section{Soll Moisture Deficits}

The long-term New Zealand climate has on the whole been favourable for plants and animals - never fully tropical; never thoroughly arid; and never entirely frigid (Suggate et al., 1980), and compares very favourably with the other main pastoral areas of the world (Maunder, 1963). However, some of the limitations of our climate have been well illustrated by the experiences of the 1970s where the increase of $30 \%$ in drought days over the previous decade caused large reductions in lambing (percentages, lamb slaughter weights, wool production (Taylor, 1980a) and dairy production (Maunder, 1977; Scott, 1978). These years may have finally killed the myth that because of a reasonably adequate and evenly spread rainfall soil moisture deficits are not a major problem in pasture production. Several authors have suggested that supplies of moisture are probably the primary environmental factor limiting the attainment of production potentials (Mitchell, 1963; Card, 1977; Radcliffe, 1979). In fact, Salinger (1979) has ascribed much of the peak growth of the pastoral industry in 1950-69 (Stephens, 1976) to the lower than average occurrence of drought in these "green years" compared with the much slower increase in gross output in the drier 1970s.

The overall influence of climate on grassland farming in New Zealand has been broadly described by Levy (1970) and the effects of extended soil moisture deficits on the development of farm systems in the drier areas east of the main ranges is well known. (Table 1).

The importance of soil type has been demonstrated by Radcliffe (1979) who showed that the general pattern of pasture production on a perennial ryegrass/white clover sward on dry

TABLE 1: Days of Soil Moisture Deficit Weighted by Sheep Population (Taylor 1980b)

\begin{tabular}{lllcc}
\hline District & $\mathbf{1 9 7 . 6 - 7}$ & $\mathbf{1 9 7 7 - 8}$ & $\mathbf{1 9 7 8 - 9}$ & $\mathbf{1 9 7 9 - 8 0}$ \\
\hline Northland/Auckland & 36.1 & 62.8 & 28.9 & 0.4 \\
Eastern districts, & & & & \\
$\quad$ North Island & 26.9 & 58.9 & 47.7 & 33.6 \\
Western districts & & & & \\
$\quad$ North Island & 24.6 & 56.0 & 27.7 & $\mathbf{1 . 9}$ \\
Marlborough/Nelson & 27.6 & 70.7 & 52.4 & $\mathbf{2 3 . 5}$ \\
West Coast & 0.0 & 0.0 & 0.0 & $\mathbf{0 . 0}$ \\
Canterbury & 57.2 & 79.8 & 41.1 & 14.3 \\
\hline
\end{tabular}


sandy soils at Flock House in the Manawatu and on free-draining pumice soils at Wairakei was similar to dryland sites in Hawke's Bay and Canterbury.

The use of annual and biennial ryegrasses (Lolium spp.) and subterranean clover for cool season growth and cocksfoot (Dactylis glomerata L.), lucerne, and to a lesser extent red clover (T. pratense L.) to combat dry summer conditions in these areas is well established, while there appears to be considerable potential for the use of species such as phalaris (Rumball, 1969), tall fescue (Goold and Hupkens van der Elst, 1980), prairie grass (Bromus wildenowii Kunth) (Lancashire, 1978), Lotus corniculatus (Charlton et al., 1978), and more drought-tolerant and persistent perennial ryegrasses (Lancashire et al., 1979). Some of these plant types will also have a very useful role in areas which are generally regarded as having less of a soil moisture deficit problem than the eastern half of the country.

In the Waikato (Baars and Coulter, 1974) and the Manawatu (Brougham, 1977) consistent and large responses to irrigation in summer and autumn have been obtained over many years from standard pasture mixtures, while the problem of feed shortages at this time of year in ryegrass/white clover pastures in these areas is greatly emphasized at higher stocking rates (Lancashire, 1977). The potential of the summer growing pasture species is also emphasized by the failure of either irrigation or alternative summer crops such as maize to show worthwhile economic returns even in intensive dairying areas (Hutton, 1978; Campbell et al., 1978).

Large fluctuations in soil moisture deficits between years have major effects on pasture and animal production (Maunder, 1979) and perhaps more importantly on the confidence of the farmer to increase stock numbers. At 23 sites throughout New Zealand, Radcliffe (1979) showed that the major variation in pasture production between years was in summer and autumn and was mainly associated with differences in summer rainfall. Broadly similar results have been presented by During et al. (1970) for the Waikato, Field (1980) for the Bay of Plenty, and O'Connor et al. (1968) for Canterbury and North Otago who also demonstrated the advantage of lucerne over ryegrass/white clover in reducing annual variation in pasture production. Clearly the other summer growing species mentioned earlier will also have the capacity to reduce this unwanted variation between years. 


\section{TEMPERATURE}

The effects of temperature on annual pasture yields and farming systems is not as significant (Radcliffe, 1979) or as variable between years as soil moisture deficits (Field 1980). For example, Mitchell (1963) pointed out that for 6 regional lowland sites throughout New Zealand light (highly correlated with temperature) and temperature were very uniform for ryegrass during the main part of the growing season, although there are strong negative correlations between ryegrass growth and high soil temperatures in summer in the north of the North Island (Baars and Waller, 1979). Some of the subtropical grasses like paspalum (Paspalum dilafatum Poir) and Kikuyu (Pennisetum clandestinum Hochst.) can make a considerable contribution to pasture and animal production in these warmer areas (Bryant and Parker, 1971; Lambert et al., 1979; Percival, 1977, 1978; Baars et al., 1980; Rumba1 1 and Boyd, 1980) and a wide range of other subtropical grasses (Taylor et al., 1976; Rumba11 and Lambert, 1980b) and also subtropical legumes (Rumba11 and Lambert, 1980a) are being evaluated. In addition, some subtropical grasses such as Sefaria have substantially outyielded temperate grass under mowing during the warm season at sites as far south as Palmerston North (Forde et al., 1976) (Table 2).

There are large regional and altitudinal diferences in cool season temperatures in New Zealand with the result that winter growth rates of pasture may vary from 20 to $25 \mathrm{~kg} \mathrm{DM} / \mathrm{ha} /$ day in the warm temperate north to $5 \mathrm{~kg} \mathrm{DM} / \mathrm{ha} /$ day at Gore (Brougham, 1980) and 3 to 5 months' cessation of growth in the South Island high country (Scott, 1979). Increasing growth rates in the spring and declining growth rates in autumn (in the absence of soil moisture deficits) are also associated with temperature changes (Brougham, 1959a; Baars and Waller, 1979; Field, 1980; Radcliffe ef al., 1981) and thus the improvement of cool season

TABLE 2: MEAN WARM SEASON YIELDS (kg/ha) OF SPECIES ON A DRY SOIL AT PALMERSTON NORTH

(Forde et al., 1976)

\begin{tabular}{lc}
\hline \multicolumn{1}{c}{ Species } & Oct./Apr. \\
\hline Digitaria decumbens & $\mathbf{1 8 2 9 0}$ \\
Setaria anceps 'Narok & 15410 \\
Phalaris aquatica 'General Select' & 12370 \\
Lolium perenne 'N ui & $\mathbf{5 2 5 0}$ \\
\hline
\end{tabular}


activity in pasture plants can assist in alleviating serious seasonal pasture deficits at this time (Campbell and Bryant, 1978; Rattray, 1978).

The combination of cool season active grasses like annual, hybrid and perennial ryegrasses with warm season grasses like cocksfoot and legumes such as white and red clover and lucerne is well established in New Zealand (Levy, 1970) and Brougham (1959b) clearly demonstrated the important role of management in optimizing the seasonal contribution of each species. Recently released cultivars such as 'Grasslands Pitau' white clover (Williams, 1980), Maku lotus (Armstrong, 1974), 'Grasslands Matua' prairie grass (Rumball, 1974) and 'Grasslands Moata' tetraploid Italian ryegrass all show improved cool season activity and their contribution to seasonal pasture productivity has been demonstrated in several different regions of the country (Goold and Douglas 1976; Lancashire, 1978; Baars and Cranston, 1978; Scott and Mills, 1981; Fraser and Vartha, 1980).

The effects of low temperatures are seen at their most extreme in the South Island high country where frost damage may restrict the use of species such as perennial ryegrass, white clover and Yorkshire fog. In such cases the use of resistant species such as tall fescue, cocksfoot and alsike clover (T. hybridum L.) is recommended (Scott, 1979).

\section{INSECT PESTS}

Whether because of a series of poor seasons, increased stocking rates, the prohibition of the use of the insecticides DDT and dieldrin, or a real increase or spread of insect populations, the problem of pasture insect pests appears to have become more important during the last 15 years. In many cases these pests are regionally based, such as black beetle (Heteronychus arator (F.) ) and soldier fly (Inopus rubriceps Macquart) in the north of the country and porina (Wiseana cervinata Walker) in the South Island and southern North Island (Pottinger, 1976). Grass grub (Costelytra zealandica White) is widespread from Hamilton south and appears to cause most damage on pumice soils and recent alluvial soils (Pottinger, 1976).

The lack of suitable and inexpensive insecticides to control many of these pests (Trought, 1980: Robertson, 1980), particularly where costs of application are high in, for example, hill country, has led to a renewed interest in the use of resistant or tolerant plant species and cultivars. Specific breeding programmes 
in lucerne have resulted in a new cultivar 'Rere' which is resistant to blue-green aphid (Acyrthosiphon kondoi Shinji) (Dunbier and Palmer, 1978) and in a white clover selection resistant to stem nematode (Ditylenchus dipsaci (Kuhn) (Filipjev) ) (Williams, 1977). Programmes in screening white clover for resistance to grass grub (Wilson and Farrell, 1980) are being actively pursued, while the identification and utilization of species such as tall fescue, cocksfoot, Lotus pedunculatus, phalaris and lucerne which are resistant or tolerant to some of these pasture pests (King and East 1980; East et al., 1980) is a major priority (Table 3).

TABLE 3: PERCENTAGE LOSSES IN HERBAGE PRODUCTION CAUSED BY GRASS GKUB IN AUTUMN AT WAIRAKEI (East et al., 1980)

\begin{tabular}{lc}
\hline \multicolumn{1}{c}{ Species } & \% Loss \\
\hline Tall fescue & 11 \\
Cocksfoot & 5 \\
Prairie grass & 31 \\
Perennial ryegrass & 85 \\
White clover & 78 \\
\hline
\end{tabular}

\section{OTHER PESTS}

Recent glasshouse and field trials have demonstrated that rootknot nematode (Meliodogyne hapla Chitwood) and the clover cyst nematode (Heterodera trifolii Goffart) may be serious pests of white clover in some regions (Healy et al., 1973; Yeates et al., 1975). In particular, Risk and Ludecke (1979) showed that clover cyst nematodes substantially reduced clover yield and establishment in Southland while selections of white clover tolerant to the two nematode species were markedly superior to Huia in Northland (B. M. Cooper, pers. comm.).

\section{GRAZING MANAGEMENT}

Most high producing intensive lowland grassland farms are subdivided and employ some form of rotational grazing on part or all of their grassed area. Some hill country properties are now adopting such systems with success (Smith and Dawson, 1977), but much of this less intensively farmed grassland area is setstocked with the result that pasture is frequently and severely grazed, particularly during periods of feed shortage. In general, erect high yielding plants with large leaves and few tillers or growing points per unit area are more suited to lax rotational grazing 
than small-leaved densely tillered, prostrate plants which are superior under more frequent and severe grazing systems. These contrasting plant types are already illustrated by existing New Zealand cultivars such as Hamua compared with Turoa red clover and Manawa compared with Ariki hybrid ryegrass, while the development of different white clover cultivars for variable management systems is discussed below.

D I S E A S E S ,

It is very diffficult to assess the overall or regional importance of diseases in New Zealand pastures because there are very few quantitative data available despite the fact that a large number of pathogens have been identified in both grasses and clovers (Latch, 1966; Latch and Skipp, 1981).

In ryegrass, crown rust (Puccinia coronafa $\mathrm{Cda}$ ) is probably the most serious and widespread disease and large yield reductions have been recorded in the southern North Island in summer and autumn (Lancashire and Latch, 1966) (Table 4). The effects are probably not as severe in southern South Island areas because of lower temperatures, whereas in the warmer areas of Northland silage crops of 'Grasslands Tama' (Lolium multiflorum Lam.) have been badly affected in late spring (A. 0. Taylor, pers. comm.) at a time when the disease is rarely serious in Palmerston North (Armstrong and Rumball, 1976). Although selection for crown rust resistance has been incorporated into breeding programmes for some years, there is no doubt that considerable improvements are required in most of the currently available ryegrass cultivars (Armstrong and Rumball, 1976).

TABLE 4: THE EFFECTS OF CROWN RUST ON THE GROWTH OF TWO PERENNIAL RYEGRASS CULTIVARS AT PALMERSTON NORTH

(Lancashire and Latch, 1966)

\begin{tabular}{lcc}
\hline & $\begin{array}{c}\text { Max. Reduction in Yield caused } \\
\text { by Crown Rust } \\
(\%)\end{array}$ & $\begin{array}{c}\text { Mean Air } \\
\text { Temperature } \\
\left({ }^{\circ} \mathrm{C}\right)\end{array}$ \\
\hline Late summer: & & \\
$\quad$ Ariki & 22 & 19.6 \\
Ruanui & 64 & \\
Auumn: & & 15.6 \\
Ariki & 17 & \\
Ruanui & 49 & \\
\hline
\end{tabular}


Stem rust (Puccinia graminis Pers.) may affect leaf growth in a number of grasses including cocksfoot (Lancashire and Latch, 1969), but its most serious effects are on seed production (Latch, 1980) and although there are no quantitative data available in New Zealand the disease has caused $90 \%$ reductions in perennial ryegrass seed yields in Oregon (Rolston, 1980). Heavy infections have been observed in ryegrass seed crops in some seasons in the Manawatu and Canterbury and the disease appears to be a major limiting factor in the successful seed multipliction of overseas late flowering perennial ryegrasses in Canterbury (Latch, 1980), where the senior author has observed the complete destruction of a seed crop infested with stem rust. Selection against the disease is a major priority in a local breeding programme for a New Zealand late flowering perennial ryegrass, but it is of concern that two recently released ryegrass cultivas, Nui and Ellett, are more susceptible to the disease than other local ryegrasses (Latch, 1980) .

Blind-seed disease (Gloeotinia temulenta (Prill and Delacr.) Wilson, Noble and Gray) can also cause serious damage to ryegrass seed crops in cool wet years (Neill and Hyde, 1939) although the incidence of the disease appears to have decreased recently, possibly because of the increased use of nitrogenous fertilizers (Hampton and Scott, 1980). Resistant cultivars have been produced overseas but none is available in New Zealand.

Another pathogen favoured by wet seasons is ergot (Claviceps paspali Stev. and Hall) in paspalum and this disease is proving a serious drawback to successful seed production of the cultivar 'Grasslands Raki' (Lancashire et al., 1980). As fungicide treatments are rendered useless by reinfection from outside the area, the only solution appears to be to grow seed crops in areas which have a reliable dry spell each summer, adequate soil moisture, and are warm enough for reasonable growth of paspalum.

Another pathogen which has very serious effects on seed produotion is head smut (Ustilago bullata Berk.) in prairie grass (Lancashire et al., 1980). The cultivar Matua was selected for resistance to the disease (Rumball, 1974) but apparently because of the development of new races of the pathogen the cultivar is now susceptible to the disease. Fungicide treatment of the seed has proved successful and diseased crops are rejected from certification.

In lucerne there has been considerable progress in producing cultivars or undertaking breeding programmes for resistance to pathogens such as verticillium wilt (V. albo-atrum Reinke and 
Berthe), bacterial wilt Corynebacterium insidiosum McCull.) H. L. Jens and certain leaf spot diseases. However, the position is far less clear in white clover and no single disease stands out as being of prime importance in New Zealand (Latch and Skipp, 1981).

In red clover, clover rot (Sclerotinia trifoliorum Erikss.) and other root and crown rots are probably important in reducing the longevity of the species but precise information is lacking (R. A. Skipp, pers. comm.) .

\section{NEW ZEALAND ECOTYPES}

Examples of ecotypic differentiation are to be found in the two most important pasture species in New Zealand, perennial ryegrass and white clover.

\section{Ecotype Differentiation in Perennial Ryegrass}

The development of ecotypes of perennial ryegrass in New Zealand is well illustrated by the classical investigations of Levy and Davies $(1929,1930)$ fifty years ago. They showed that commercial lines of perennial ryegrass harvested from permanent grassland areas in the North Island, particularly Hawke's Bay and Poverty Bay, were markedly different from those from arable farm. ing areas in the South Island. The former, "true" perennial ryegrass, consisted predominantly of dark green, dense-tillered, longlived plants, while the latter, "false" perennial ryegrass, were characteristically open-tillered, free-flowering and short lived.

In common with most of our adventive pasture species, perennial ryegrass (Lolium perenne L.) is cross-fertilized and by no means true-breeding. Also, it is interfertile with the closely related but annual Italian ryegrass ( $L$. multiflorum Lam.), and the hybrids are extremely variable with a range of characteristics between the two parent species. The ryegrass ecotypes described by Levy and Davies evolved from such heterogeneous populations through the selection pressure of two distinct farming systems an arable system in which harvesting seed in the first year and repeated sowing and harvesting favoured the dominance of shortlived, free-seeding types, and a permanent pasture system where seed was infrequently harvested, favouring true perennial types which persisted not by reseeding but by vigorous vegetative reproduction. Natural selection towards these extremes would be accentuated if seed for further sowing was used in the region from 
which it was general practice to sow seed of local origin (Levy and Davies, 1930).

Following these investigations and so that the superior "true" perennial ecotype could be identified and maintained, a seed certification scheme devised by J. W. Hadfield was introduced by the Department of Agriculture (Hadfield, 1929). This scheme, still applied to all acceptable cultivars, is essential for the maintenance of strain purity. Following its introduction, inferior strains rapidly disappeared from the seed market and were replaced by certified seed of the true perennial ryegrass ecotype.

Another perennial ryegrass ecotype quite distinct from that of Hawke's Bay has in more recent times been identified by T. R. Ellett as originating on his farm at Mangere. We are indebted to Mr Ellett for information on the history of the property which was purchased by his grandfather in 1863 and has been in the family ever since. In the early years, crops of wheat were grown and the areas resown with "English" grasses. From the turn of the century until about twenty years ago, no cultivation and re: sowing of grass seed had taken place. Stocking has been either with dry stock or dairy cattle under a lax grazing system with opportunity for reseeding.

The climate is mild with a few light frosts. The mean annual rainfall is $1200 \mathrm{~mm}$, usually with low precipitation in summer. The volcanic soil is of basaltic origin, of moderate fertility, freedraining, friable and prone to severe moisture deficit in dry summers.

The Mangere ecotype is quite distinct from the Hawke's Bay ecotype and 'Grasslands Ruanui' perennial ryegrass. It is more erect with larger leaves and tillers, has higher winter production, is more resistant to summer drought, and responds more rapidly and vigorously to autumn rains. These features are. consistent with those which would be expected in the evolution of an ecotype from a mixed population of ryegrass subject over a long period to the particular conditions of climate, soil and management that prevailed on the Ellett property. Lax grazing would favour its erect and bulky growth form, the mild winter its winter growth and rapid autumn recovery, and the light soil and dry summers its resistance to drought. These characteristics have been confirmed in the case of Nui (derived from the Mangere ecotype) which has been shown to be favoured by infrequent mowing or grazing in both the United Kingdom and New Zealand (Lancashire et al., 1979; A. J. Harris, pers. comm.). 


\section{Ecotype Differentiation in White Clover}

In white clover, Davies and Levy (193 1) described four major types indigenous to New Zealand at that time. In addition to identification of the types, these workers also defined the ecological adaptations of each. These definitions form the basis of regional breeding in white clover,

The four white clover types were:

Type 1: N.Z. Wild White No. 1. An outstanding medium-leaved perennial with high productivity growing in highly fertile old pastures, especially on the Heretaunga Plains and in the Sefton-Rangiora district of Canterbury.

Type 2: N.Z. Wild White No. 2. A denser and smaller leaved perennial type than No. 1 with lower productivity. Found on less fertile soils, especially in old Hawke's Bay pastures.

Type 3: Ordinary N.Z. White. A non-persistent form with reasonable first-year growth, early free-flowering and poor second year production, especially in winter. Medium leaves.

Type 4: Lax early-flowering New Zealand (and ordinary European) White. An extremely non-persistent (annual) type with low productivity and small leaves.

These four New Zealand types showed a gradation in distribution with soil fertility. Ordinary N.Z. White was found mainly on soils of low-average fertility. The poorest types occurred in the arable districts of South Canterbury where crop rotation and regular dry summers may have favoured free-seeding annual types. There was also evidence that farming system affected distribution of clover type. On high fertility soils, cattle grazing favoured No. 1 and sheep grazing No. 2 (Levy and Gorman, 1934).

More recently, comprehensive sampling of pastures on moist hill country farms has indicated the existence of a small-leaved prostrate type adapted to this enviroament (Forde and Suckling, 1977).

\section{CULTIVARS}

Following the identification of ecotypes and certification of the best, plant breeders commenced breeding improved cultivars of the most widely sown grassland species. The ecotypes had proved their value in New Zealand grasslands far beyond the regions in which they had originated. Within a few years after the establishment of the certification scheme for perennial ryegrass and white 
clover, certified seed had largely supplanted that of uncertified origin. Breeding programmes using the ecotypes as a base were designed to eliminate inferior plants and by plant selection and progeny testing to improve yield, seasonal spread of production and persistency, and at the same time to retain wide regional adaptability.

From this work originated the two most widely used cultivars in New Zealand, 'Grasslands Ruanui' perennial ryegrass and 'Grasslands Huia' white clover (Corkill, 1949) . Both are adaptable to a wide range of environmental conditions and grazing practices. They are still the most generally used for sown pastures in New Zealand and are used also quite extensively in the United Kingdom and in other countries with climates not greatly dissimilar to that of New Zealand.

\section{REGIONAL BREEDING}

As already outlined, New Zealand consists of a patchwork of environments which differ greatly in their influence on the performance of pasture plants. A multiplicity of species and cultivars would be necessary to fill all requirements for high plant performance under all conditions. A single cultivar of any species would not be expected to provide the answer to all conditions as well as a number of regional cultivars.

\section{Plant Collection}

Different approaches can be used in breeding regional cultivars. The basis for a cultivar appropriate to à particular region may already be present in an ecotype which has developed in a similar region. For example, 'Grasslands Nui' perennial ryegrass (Armstrong, 1977) and Ellett perennial ryegrass are based on the Mangere ecotype which is strongly adapted to summer drought and responds vigorously to autumn rains.

Some of the older cultivars still in use were produced by selection from New Zealand ecotypes - e.g., Ruanui perennial ryegrass from the Hawke's Bay/Poverty Bay ecotype, Apanui cocksfoot from the Akaroa ecotype, and Huia white clover from the No. 1 white clover ecotype (Corkill, 1949).

There is no doubt that further search will reveal regional ecotypes well adapted to particular environmental conditions. There is still a very important place in New Zealand grasslands for a perennial ryegrass cultivar which will withstand intense grazing 
pressure in regions with a severe summer moisture deficit, for example, in such regions as North Canterbury. Collections are being made from old-established perennial ryegrass pastures of plants which will withstand these conditions.

A further example of regional breeding is the current Grasslands Division programme to breed a white clover for moist hill country. Forde and Suckling (1977) showed that the white clover occurring on hill country farms is very small leaved, prostrate and relatively unproductive compared with Huia white clover. Williams and Caradus (1978) found that this small-leaved form persisted better than Huia and outproduced it after two to three years in hill country pasture. A selection programme is being carried out to breed an improved form of this hill country type of clover. Table 5 shows the performance of breeding lines of the hill country type in hill country and on lowland in autumn 1980, two years after planting. The hill country types were clearly inferior to Huia on lowland and clearly superior in hill country pastures. This work is still proceeding and selection of the best breeding lines should result in a cultivar substantially better than Huia for hill country. However, Huia will remain superior on high fertility lowland.

TABLE 5: MEDIAN YIELD SCORES OF 122 HILL COUNTRY WHITE CLOVER LINES, RELATIVE TO HUIA $(=100)$ AT TWO HILL COUNTRY SITES AND ONE LOWLAND SITE. APRIL 1980

\begin{tabular}{cc}
\hline Site & Relative Growth Score \\
\hline Low fertility hill country: & \\
Ballantrae, sunny aspect & 153 \\
Ballantrae, shady aspect & 175 \\
High fertility lowland: & 66 \\
Aorangi spaced plants & 66 \\
\hline
\end{tabular}

It is possible to broaden the adaptability of a species to a given situation or region by breeding cultivars specifically for that situation or region, and it is important that we continue to make collections from regions in New Zealand for that purpose.

\section{Plant INTRODUCTION}

Plant introduction either to locate overseas cultivars which could be of use in New Zealand grassland farming, or, alternatively, as a source of genes for plant breeding, has been extensively used. 
In the first category are R.v.P. Vigor and S23 late-heading perennial ryegrasses which are on the New Zealand National List of Acceptable Cultivars, and cultivars of other species including phalaris, tall fescue, subterranean clover, strawberry clover $(T$. fragiferum L.) and lucerne.

Several cultivars have been developed by selection from within overseas introductions - e.g., Kahu timothy, Turoa Montgomery red clover, Matua prairie grass, Mar-u phalaris, Roa tall fescue, Raki paspalum, and G17 cocksfoot. Paroa Italian ryegrass, Tama Westerwolds ryegrass, Pitau white clover, Pawera red clover and Maku lotus all incorporate overseas plant material.

Introductions originating in Mediterranean regions have been used in breeding cultivars with improved cool season production, particularly in the ryegrasses, white clover and lotus. Mediterranean material when hybridized with New Zealand naturalized ecotypes has markedly improved cool season growth in several of our important species. This concept was used to perhaps its greatest effect in breeding H1, or 'Grasslands Manawa' ryegrass from a hybrid population between perennial and Italian ryegrasses (Corkill, 1945). Later 'Grasslands Ariki' was developed as a perennial ryegrass with some degree of Italian ryegrass influence by backcrossing $\mathrm{H} 1$ to New Zealand perennial ryegrass (Barclay, 1963b). The same concept was used by Barclay (1960, 1963a, 1969) in developing 'Grasslands Pitau' white clover from Spanish $X$ New Zealand hybrids. 'Grasslands Maku' lotus was developed from Portuguese X New Zealand hybrids (Armstrong, 1974).

This Mediterranean influence, while having a clear impact on pasture plant breeding generally, has also introduced a regional element into plant performance. This is because the Mediterranean adaptation is for survival of hot, dry summers, with growth occurring in mild winter conditions. Two forms of adaptation for summer survival are found - improved drought tolerance in perennial forms associated with summer dormancy, and profuse early flowering, free-seeding annual forms. The adaptation to cool reason growth is generally associated with reduced winterhardiness.

These characteristics result in different plant performances in different regions. Italian ryegrass is an example of the free-seeding annual adaptation to summer survival. If Italian ryegrass receives moisture in summer it will, however, survive vegetatively. As a consequence of this, the longer lived forms derived from Italian ryegrass - i.e., 'Grasslands Manawa' and 'Grasslands Ariki' persist better in regions with moist summers. 
Pitau white clover is also more winter-active than Huia, a characteristic which is expressed in northern regions with relatively mild winters, but not in the southern half of the South Island (Table 6) ; Barclay, 1969; Brock, 1971, 1974; Brown, 1973; During and Weeda, 1974; Goold and Douglas, 1976; Lambert et al., 1969; McDonald and Cullen, 1973).

TABLE, 6: CLOVER YIELDS IN PITAU-BASED PASTURES RELATIVE TO HUIA-BASED PASTURES

\begin{tabular}{lc}
\hline North Island' & 122 \\
Annual yield of Pitau & 160 \\
Cool season yield of Pitau & \\
South Island & 93 \\
Annual yield of Pitau & 117 \\
Cool season yield of Pitau & \\
\hline
\end{tabular}

18 trials at 6 locations.

2 6 trials at 5 locations (all in Canterbury, Otago, Southland).

Regional testing of other Mediterranean populations (B. M. Cooper and K. M. Widdup, pers. comm.) shows large differences in performance in the north (Kaikohe) and the south (Gore). Figure 1 shows the mean seasonal growth scores from spaced plants of an experimental line of Huia white clover crossed with Mediterranean materials (from Morocco, Algeria and Italy) at Kaikohe and Gore. While a cool season growth peak is shown at both locations, the general level of growth in the south is similar to Huia while in the north large growth advantages are observed for the Mediterranean line.

Similar trends are shown by other Mediterranean-derived populations, indicating that there is potential for further improvement of white clover in the north by use of Mediterranean material. Such material provides advantages for both growth in the cool seasons and survival of summer drought (Williams et al., 19771.

Improvement in cool season growth is more useful in the north for two reasons. First, there is already quite marked growth at that time of year and so any improvement is significant. In the south, by contrast, there is so little cool sea-son growth that even doubling it would contribute little to total production. Second, in the north subtropical grasses have considerable use, but these have a summer growth peak which normally conflicts with the growth peak of white clover. By improving the cool season performance 


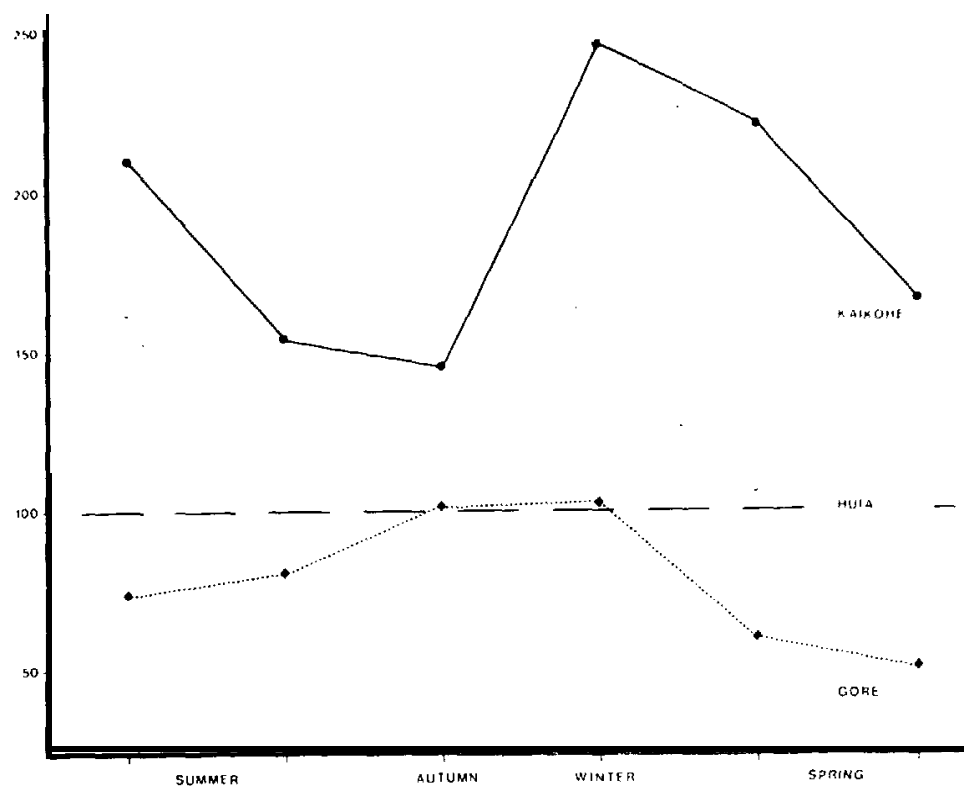

FIG. 1: Seasonal growth curves of a Mediterranean whife clover line (C2156) relative fo 'Grasslands Huia' at Kaikohe and Gore.

of white clover, we are not competing with the subtropical grasses and are helping to fill the cool season gap in subtropical grass growth.

There is also considerable potential for cool season growth in lucerne in the North Island and the regional breeding programme is utilizing overseas material to improve this characteristic. In addition, some leaf diseases appear to be a greater problem in the North Island and are therefore also receiving close attention $(\mathrm{H}$. S. Easton, pers. comm.).

The New Zealand perennial ryegrass ecotypes and cultivars are all early heading but some European cultivars are five or six weeks later and thus maintain vegetative growth longer in the late spring which may be an advantage particularly for fat lamb farming. However, all of the late-heading cultivars tested here have extremely low seed yields compared with early-heading cultivars. A survey in Canterbury indicated that the prime reason for the low yield is susceptibility of the late heading cultivars to stem rust (Puccinia graminis Pers.) which severely inhibits seed devel- 
opment. Selection is being undertaken for resistance to stem rust and improved seed yield.

Plant introduction has made a very significant contribution to plant improvement in New Zealand and it is clear that we should continue to utilize overseas sources of plant material and obtain further plant collections.

\section{Special Problems}

Special problems are presented by pests and diseases such as grass grub, porina, and nematodes. It has become very expensive to treat pastures to eliminate such pests by chemical means and the breeding of resistant plants has therefore become a priority. Among the grasses, ryegrass and browntop are susceptible to grass grub while phalaris is resistant and tall fescue tolerant. Lucerne and lotus are resistant to grass grub but clovers are generally very susceptible (Kain and Atkinson, 1970, 1977; Farrell and Sweney, 1974; East et al., 1980).

The impact of selection for resistance to pest attack can be illustrated by a Grasslands programme to select for resistance to stem eelworm attack in Pitau white clover. Table 7 shows that before eelworm attack neither the Spanish line nor the resistant selections differed significantly in growth from Pitau. However, after eelworm attack the very susceptible Spanish line was virtually eliminated and the resistant selections were significantly superior in growth score to Pitau, which is moderately susceptible. Thus,

TABLE 7: GROWTH SCORES BEFORE AND AFTER EELWORM ATTACK ON A SPANISH INDICATOR LINE AND THREE WHITE CLOVER SELECTIONS RELATIVE TO PITAU $(=100)$ (After Williams 1977)

\begin{tabular}{|c|c|c|c|c|}
\hline Selected Line & $\begin{array}{l}\text { Growth } b \\
\text { Spanish }\end{array}$ & $\begin{array}{l}\text { before Eelw } \\
\text { Attack } \\
\quad \text { Selected } \\
\quad \text { line }\end{array}$ & $\begin{array}{c}\text { Growth } a \\
A t \\
\text { Spanish }\end{array}$ & $\begin{array}{l}\text { er Eelworm } \\
\text { Selected } \\
\text { line }\end{array}$ \\
\hline $\begin{array}{l}\text { (a) First field selection } \\
\text { (median of } 39 \text { lines) }\end{array}$ & $93 \pm 7$ & $113 \pm 7$ & $17 \pm 15 \dagger$ & $173 \pm 15^{*}$ \\
\hline $\begin{array}{l}\text { (b) Second field selection } \\
\text { (median of } 22 \text { lines) }\end{array}$ & $74 \pm 12$ & $126 \pm 12$ & 0 & $170 \pm 22^{*}$ \\
\hline (c) Third field selection & $116 \pm 12$ & $114 \pm 12$ & $3 \pm 20 \dagger$ & $275 \pm 20 *$ \\
\hline
\end{tabular}

* . Significantly better than control $(P<0.05)$.

$\dagger$ : Significantly poorer than control $(P<0.05)$ 
while there was little difference among the clover lines in the absence of eelworm, where eelworm was present the three lines differed markedly in performance.

\section{BREEDING FOR OVERSEAS}

So far no pasture plant breeding has been done in New Zealand with the objective of developing a cultivar specifically for overseas use. Some New Zealand cultivars have nevertheless performed well in other countries-e.g., Huia white clover accounts for more than 90\% of the white clover seed sown in the United Kingdom and indeed for approximately $70 \%$ of the world export trade in white clover. The New Zealand grass and clover export seed trade, which is a spin-off from the domestic industry, amounted to more than $\$ 11$ million in overseas returns in 1979-80, less than 0.5\% of total returns from pastoral agriculture. Robertson (1980) has suggested that New Zealand should improve this situation by breeding for specific overseas markets.

The technical requirements for such breeding are germplasm, expertise and facilities in overseas countries for plant evaluation and selection. The recent introduction of Plant Selectors' Rights and the consequent entry of New Zealand seed firms into plant breeding could provide a means for achieving the breeding of cultivars for overseas markets. Most New Zealand seed firms are associated with overseas plant breeding companies with comprehensive testing facilities in diverse regions.

New Zealand germplasm which is well adapted to maritime climates in several parts of the world could therefore be evaluated, selected and hybridized in overseas locations through overseas plant breeding firms. The value of this to New Zealand growers and seed merchants would depend on commercial factors. The excellent performances of cultivars not specifically selected for overseas environments suggest that there could be considerable potential. A structure is available through the seed firms but commercial success would be dependent on the ability to produce seed in New Zealand. At present there are potential difficulties, especially with white clover, because of the problem of large buried seed loads (Suckling and Charlton, 1978):

\section{REFERENCES}

Allan, H. H., 1937. Proc. Linn. Soc. Pt. I: 25-46.

Armstrong, C S., 1974. N.Z. Jl exp. Agric., 2: 333-6. 1977. Ibid., 5: 381-4. 
Armstrong, C. S.; Rumball, W., 1976. Proc. N.Z. G rassId A ss., 37: 208-14. Baars, J. A.; Coulter, J. D., 1974. I bid., 35: 197-203.

Baars, J. A.; Cranston, A., 1978. I bid., 39: 139-47.

Baars, J. A.; Percival, N. S.; Goold, G. J.; Weeda, W. C., 1980. I bid., 41: 89-95.

Baars, J. A.; Waller, J. E., 1979. Proc. Agron. Soc. N.Z., 9: 101-4.

Barclay, P. C., 1960. Proc, 8th int. Grassld Congr.: 326-30.

1963a. Sheepfmg A.: 103-9. 1963b. Proc. N.Z, Grass

1969. Ibid., 31: 127-34.

Blakemore, S. D., 1978. Soil and Wafer, 14 (2): 24-6.

Brock, J. L., 1971. N.Z. Jl agric. Res., 14: 368-78. 1974. N.Z. Jl exp. Agric., 2: 365-9.

Brock, J. L.; Charlton, J. F. L., 1978. Proc. N.Z. G rassId A ss., 39: 121-9. Brougham, R. W., 1959a. N.Z. Jl agric. Res., 2: 283-96 1959b. I bid., 2: 123218.

1977. Int. Mtg Anim. Prod, from Temp. Grassld: 140-6. 1980. Proc. 2nd dust. Conf. Invert. Ecol.: 16-23.

Brown, K. R., 1973. N.Z. $J$ exp. A gric., I: 165-70.

Bryant, A. M.; Parker, 0. F., 1971. Proc. Ruakura Fmrs' Conf., 23: 110-20.

Campbell, D. A., 1947. Bull. No. 5. Soil Conservation and Rivers Control Council, Wellington.

Campbell, A. G.; Bryant, A. M., 1978. Proc. A gron. Soc. N.Z., 8: 115-8.

Campbell, A. G.; Clayton, D. G.; Macdonald, K. A., 1978. Aglink FPP 166. MAF, Wellington.

Caradus, J. R.; Dunlop, J., 1978. In Proc, 8th mtg Colloq. Pl. Anal. and Fert. Prob. N.Z. DSIR Inf. Ser. 134.

Card, K. A., 1977. Rep. No. 564. Physics and Engineering Laboratory, DSIR, Lower Hutt.

Charlton, J. F. L.; Wilson, E. R. L.; Ross, M. D., 1978. N.Z. Jl exp. A gric., 6: 201-6.

Corkill, L., 1945. N.Z. Jl A gric., 71: 465-70.

Davies, W.; Levy, E. B., 1931. N.Z. Jl Agric., 42: 75-89.

- ; 1931. I bid., 42: 151-64.

Dunbier, M. W.; Palmer, T. P., 1978. Aglink FPP 147. MAF, Wellington.

During, C.; Mitchell, K. J.; Lancaster, R. J., 1970. In N ew Z ealand B eef Production, Processing and Marketing. N.Z. Institute of Agricultural Science, Wellington.

During, C.; Weeda, W. C., 1974. N.Z. $/ l$ exp. A gric., 2: 23-5.

East, R.; Kain, W. M.; Douglas, J. A., 1980. Proc, N.Z. Grassld Ass., 41: $105-15$

Farnsworth, M. C.; Male, A. J. R.; Russell, I., 1975. Ibid., 37: 32-51.

Farrell, J. A. K.; Sw eney, W. J., 1974. N.Z. Jl agric. R es., 17: 69-72.

Field, T. R. O., 1980. Proc. N.Z, Grassld Ass., 41: 80-8.

Forde, B. J.; Slack, C. R.; Roughan, P. G.; Whitehead, H. C., 1976. Ibid., 19: $135-42$.

Forde, M. B.; Suckling, F E. T., 1977. Proc. 3rd int. SA BR A O Congr., 2 (14b); $15-8$.

Fraser, T. W.; Vartha, E. W., 1980. Proc. N.Z. G rassld Ass., 41: 50-5.

Gibbs, H. S., 1963. Proc. N.Z. Inst. A gric. Sci., 9: 63-79.

Goold, G. J.; Douglas, J. A., 1976. N.Z. Il exp. A gric., 4: 13541. 
Goold, G. J.; Hupkens van der Elst, F. C. C., 1980. Proc, N.Z. Grasslds Ass., 41: 130-7.

Guthrie-Smith, H., 1930. N.Z. Jl A gric., 40:84- 92.

Hadfield, J. W., 1929. N.Z. Il Agric., 39: 289-95.

Hampton, J. G.; Scott, D. J., 1980 N .Z. /l agric. R es., 23: 143-53.

Healy, W. B.; Widdowson, J. P.; Yeates, G. W., 1973. I bid., 16: 70-6.

Hutton, J. B., 1978. Aglink FP P 167, MAF, Wellington.

Jacques, W. A., 1974. Proc. N.Z. Grassld Ass., 36: 249-57.

Kain, W. M.; Atkinson, D. S., 1970. Proc. N.Z. Weed \& Pest Control Conf., 23: 180-3.

___ - 1977. N.Z. Jlagric. Res., 20: 507-17.

King, M., 1969. Proc. N.Z. Grassld Ass., 31: 80-7.

King, P. D.; East, R., 1980. Proc. 2nd Aust. Conf. Grassld Invert. Ecol.: 79.82.

Lambert, J. P.; Vartha, E. W.; Harris, A. J., 1969. Proc. N.Z. G rassld Ass., 31: $135-42$.

Lambert, J. P.; Rumball, P. J.; Boyd, A. F., 1979. N.Z. /l exp. A gric., 7: 295.302.

Lancashire, I. A., 1977. Massey Dairyfmg A.: 40-50.

1978. Proc. Agron. Soc. N.Z., 8: 123-8.

Lancashire, J. A.; Harris, A. J.; Armstrong, C. S.; Ryan, D. L., 1979. Proc. N.Z. Grassld Ass., 40: 114-124.

Lancashire, J. A.; Hampton, J. G.; Gomez, J. S., 1980. In Herbage Seed Production. G rassld Res. \& Pract. Ser. No. 1 N.Z. Grassld Ass.

Lancashire, J. A.; Latch, G. C. M., 1966. N.Z. Il agric. R es., 9: 628-40.

- 1969 . Ibid., 12: 697-702

Latch, G. C. M., 1966. Ibid., 9: 394-409.

- 1980. In Herbage Sced Production. G rassId R es. \& Pract. Ser. No. 1. N.Z. Grassld Ass.

Latch, G. C. M.; Skipp, R. A., 1981. In The W hite Clover Plant. CAB. Hurley (in press).

Levy, E. B., 1970. Grasslands of New Zealand. Govt Printer, Wellington.

Levy, E. B.; Davies, W., 1929. N.Z. Il Agric., 39: 1-8.

1930. Ibid., 40: 363-85.

Levy, E. 'B.; Gorman, L. W., 1934. I bid., 49: 86-104.

Lowther, W. L., 1977. Proc, N.Z. Grassld Ass., 38: 133-9.

McDonald, 1. R.; Cullen, N. A., 1973. I bid., 34: 161-8.

Mauger, J. H.,1977. N.Z. Jl Agric., 134 (3): 40-2

Maunder, W. J., 1963. Proc. N.Z. Inst. A gric. Sci., 9: 25-40. 1977. N.Z. agric. Sci., 11: 110-9.

1979. In Symposium on the Value of Meteorology in Economic Planning. N.Z. Meteorological Service, Wellington.

Mitchell, K. J., 1963. Proc. N.Z. Inst. Agric. Sci. 9: 80-96.

Morton, J. D., 1981. Proc. N.Z. G rassld A ss., 42: 123-30.

Neill, J. C.; Hyde, E. 0. C., 1939. N.Z. Il Sci. Technol., 20A: 281-301.

Nordmeyer, A. H.; Davis, M. R., 1977. Proc. N.Z. Grassld Ass., 38: $119-25$.

O’Connor, K. F.; Vartha, E. W.; Belcher, R. A. .Coulter, J. D., 1568. Ibid, 30: 50-63.

Percival, N. S., 1977. N .Z. Jl exp. A gric., 5: 219-26.

1978. I bid., 6: 19-21.

Pottinger, R. P., 1976. Proc. N.Z. Soc. Anim. Prod,, 36: 12-22. 
Radcliffe, Y. E., 1979. In Symposium on the Value of Meteorology in Economic Planning. N.Z. Meteorological Service, Wellington.

Radcliffe, J. E.; Scott, D.; O'Connor, K. F., 1981. N.Z. Jl agric. Res., 24 (in press).

Rattray, P. V., 1978. Proc. Agron. Soc. N .Z., 8: 103-S.

Risk, W.; Ludecke, T. E., 1978. Proc. N.Z. Grassld. A ss:, 40: 51-9.

Robertson, G. B., 1980. In Herbage Seed Production. Grassld Res. \& Pract. Ser. N 0. 1. N.Z. Grassld Ass.

Robertson, L. N., 1980. Proc. 2nd A ust. Conf. Grassld Invert. Ecol.: 167-70.

Rolston, M. P., 1980. In Herbage Seed Production. Grassld. Res. \& Pract. Ser. No. 1. N.Z. Grassld Ass.

Rumball, W., 1969. Proc, N.Z. Grassld A ss., 31: 35-42.

1974. N.Z. Il exp. A gric., 2: 1-5.

Rumball, P. J.; Boyd, A. F., 1980. I bid., 8: 21-6.

Rumball, P. J.; Lambert, J. P., 1980a. Ibid., 8: 179-83.

1980b. Ibid. (in press).

Salinger, M. J., 1979. In Symposium on the Value of M eteorology in Economic Planning. N.Z. Meteorological Service, Wellington.

Saxby, S, H., 1956. In Pasture Production in New Zealand. N.Z. Depi. Ágric. Bull. 250.

Saunders, W. H. M., 1980. N.Z. Soil N ews, 28: 44-54.

Scott, D., 1979. In Hill and High Country Seminar. Spec. Pub. No. 16. Tussock Grasslands \& Mountain Lands Institute, Lincoln College.

Scott, J. D. J., 1978. Aglink FPP 161. MAF, Wellington.

Scott, R. S.; Mills, E G., 1981. Proc. N.Z. Grassld A sS., 42: 131-41.

Sheath, G. W., 1981. Ibid., 42: 160-S.

Smith, M. E.; Dawson, A. O., 1977. Ibid., 38: 47-55.

Stephens, P. R., 1976. N ew Zealand A tlas. Govt Printer, Wellington.

Suckling, F. E. T.; Charlton, J. F. L., 1978. N.Z. JI exp. A gric., 6: 211-5.

Suggate, R. P.; Stevens, G. R.; Te Punga, M. T., 1980. In The Geology of $\mathrm{N}$ ew Zealand. Govt Printing Office, Wellington.

Taylor, A. 0.; Rowley, J. A.; Hunt, B. J., 1976. N.Z. Jl agric. Res., 19: $127-33$.

Taylor, N. W., 1980a. Paper No. 1928. N.Z. Meat and Wool Boards' Economic Service, Wellington.

1980b. Paper N 0. 1850. Ibid.

Trought, T. E. T., 1980. Proc. 2nd A ust. Conf. Invert. Ecol.: 160-5.

Williams, W. M., 1977. Proc. 3rd int. SA BRA O Congr., 2 (14b): 19-23. 1980. A glink FPP 347. MAF, Wellington.

Williams, W. M.; Anderson, L. B.; Cooper, B. M., 1977. Proc. N.Z. Grassld A ss., 39: 130-S.

Williams, W. M.; Caradus, J. R., 1978. Ibid., 40: 162-9.

Wilson, E. R. L.; Farrell, J. A. K., 1980. Proc. 2nd Aust. Conf. Invert. Ecol.: 91-4.

Yeates, G. W.; Healy, W. B.; Widdowson, J. P.; Thomson, N. A.; MacDiarmid, B. N., 1975. N.Z. Il agric. Res., 18: 411-6. 